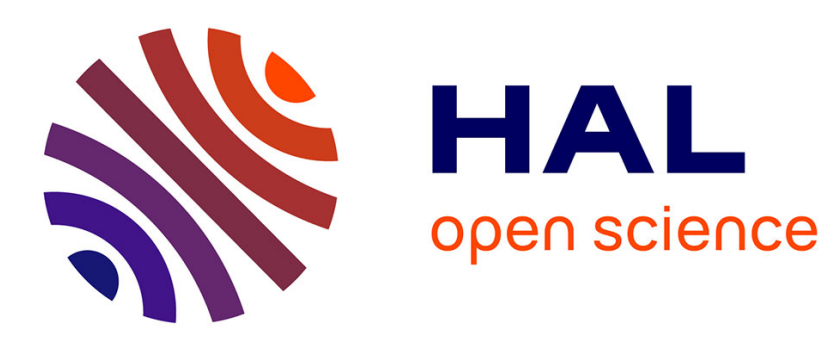

\title{
The method Heliosat-2 for deriving shortwave solar radiation from satellite images
}

Christelle Rigollier, Mireille Lefèvre, Lucien Wald

\section{To cite this version:}

Christelle Rigollier, Mireille Lefèvre, Lucien Wald. The method Heliosat-2 for deriving shortwave solar radiation from satellite images. Solar Energy, 2004, 77 (2), pp.159-169. hal-00361364

\section{HAL Id: hal-00361364 \\ https://hal.science/hal-00361364}

Submitted on 13 Feb 2009

HAL is a multi-disciplinary open access archive for the deposit and dissemination of scientific research documents, whether they are published or not. The documents may come from teaching and research institutions in France or abroad, or from public or private research centers.
L'archive ouverte pluridisciplinaire HAL, est destinée au dépôt et à la diffusion de documents scientifiques de niveau recherche, publiés ou non, émanant des établissements d'enseignement et de recherche français ou étrangers, des laboratoires publics ou privés. 
THE METHOD HELIOSAT-2 FOR DERIVING SHORTWAVE SOLAR

\section{RADIATION FROM SATELLITE IMAGES}

Rigollier C.+, Lefèvre M., Wald L.***

Groupe Télédétection \& Modélisation, Ecole des Mines de Paris, BP 207, 06904 Sophia Antipolis cedex, France.

${ }^{+}$Christelle Rigollier is now with Silogic, Toulouse, France

\section{ABSTRACT}

This article presents the method Heliosat-2 that converts observations made by geostationary meteorological satellites into estimates of the global irradiation at ground level. This new version integrates the knowledge gained by various exploitations of the original method Heliosat and its varieties in a coherent and thorough way. It is based upon the same physical principles but the inputs to the method are calibrated radiances, instead of the digital counts output from the sensor. This change opens the possibilities of using known models of the physical processes in atmospheric optics, thus removing the need for empirically defined parameters and of pyranometric measurements to tune them. The ESRA models are used for modeling the clear-sky irradiation. The assessment of the ground albedo and the cloud albedo is based upon explicit formulations of the path radiance and the transmittance of the atmosphere. The method Heliosat-2 is applied to Meteosat images of Europe for the months of January 1995, April 1995 and July 1994. Pyranometric measurements performed by thirty-five meteorological stations are used to assess the performances that are close to those of Heliosat-1 found in the literature. Possible improvements are discussed.

Keywords: turbidity, atmosphere optics, radiation, image processing, meteorology, mapping, albedo, cloud, clearness index, software, Meteosat

\section{NOMENCLATURE}

$t \quad$ time.

${ }^{*}$ Corresponding author: fax +33 493957535; lucien.wald@ensmp.fr 
$(i, j) \quad$ space coordinates of a pixel in an image.

$\theta_{S} \quad$ sun zenithal angle for the pixel under concern.

$I_{0} \quad$ solar constant, equal to $1367 \mathrm{~W} \mathrm{~m}^{-2}$.

$\varepsilon \quad$ correction used to allow for the variation of sun-earth distance from its mean value.

$G^{t}(i, j)$ and $D^{t}(i, j)$ respectively the horizontal global and diffuse irradiances at ground level, in $\mathrm{W} \mathrm{m}^{-2}$.

$G_{c}^{t}(i, j)$ and $D_{c}^{t}(i, j) \quad$ respectively the horizontal global and diffuse irradiances at ground level under clear $\mathrm{sky}$, in $\mathrm{W} \mathrm{m}^{-2}$.

$G_{h}(i, j)$ and $D_{h}(i, j) \quad$ respectively the horizontal global and diffuse hourly irradiations at ground level for the hour, i.e. the integral of the irradiance observed during one hour $\left(\mathrm{Wh} \mathrm{m}^{-2}\right)$. Similar notations hold for the daily irradiations, with a subscript $d$.

$G_{c h}(i, j)$ and $D_{c h}(i, j) \quad$ respectively the horizontal global and diffuse hourly irradiations at ground level under clear sky for the hour $h\left(\mathrm{Wh} \mathrm{m}^{-2}\right)$. Similar notations hold for the daily irradiations, with a subscript $d$.

$K_{c}^{t}(i, j) \quad$ clear-sky index (unitless).

$T_{L}(A M 2)$ Linke turbidity factor for a relative air mass $m$ equal to 2 (unitless).

$m \quad$ relative optical air mass.

$\delta_{R}(m) \quad$ integral Rayleigh optical thickness.

$T_{r B} \quad$ transmission function for beam radiation (unitless).

$T_{r d} \quad$ transmittance at zenith for the diffuse component and $F_{d}\left(\theta_{S}\right)$ the angular correction (unitless).

$L^{t}(i, j) \quad$ radiance observed by the spaceborne sensor, expressed in $\mathrm{W} \mathrm{m}^{-2} \mathrm{st}^{-1}$.

$I_{\text {Omet }}$ total irradiance in the visible channel for the various Meteosat sensors, that is the result of the convolution of the spectral distribution of $I_{0}$ by the spectral sensitivity curve of the radiometer.

$\rho^{t}(i, j) \quad$ apparent albedo observed by the spaceborne sensor.

$\rho_{\text {cloud }}^{t}(i, j)$ apparent albedo observed by the spaceborne sensor over the brightest clouds (unitless) and is a quantity specific to the method Heliosat.

$\rho_{\text {eff }}^{t}(i, j) \quad$ effective albedo for clouds (unitless).

$\rho_{g}^{t}(i, j) \quad$ apparent albedo observed by the spaceborne sensor over the ground under clear skies (unitless).

$\theta_{v} \quad$ satellite viewing angle, formed by the normal to the ground and the direction of the satellite for the pixel under concern. It is the complement to $90^{\circ}$ of the satellite altitude angle above horizon.

$\psi \quad$ difference between the sun and satellite azimutal angles. 
$b(t) \quad$ calibration coefficient and is the radiance measured when viewing darkness (Rigollier et al. 2002), in $\mathrm{W} \mathrm{m} \mathrm{m}^{-2} \mathrm{st}^{-1}$.

$n^{t}(i, j) \quad$ cloud index (unitless).

\section{INTRODUCTION}

Several authors have shown the potentialities of the images of the Earth taken by the meteorological satellites for the mapping of the global irradiation impinging on a horizontal surface at the ground level. Zelenka et al. (1992, 1999) and Perez et al. (1997) demonstrate that for the best methods and for pixels of size of $10 \mathrm{~km}$ or so, the irradiation assessed by satellite is better than that estimated by the means of an interpolation technique applied to measurements performed at meteorological stations as soon as the distance to the stations is greater than $34 \mathrm{~km}$ for the hourly irradiation and $50 \mathrm{~km}$ for the daily irradiation.

Many methods were developed especially in the years '80s. Among them was the method called Heliosat-1 (Cano 1982; Cano et al. 1986; Michaud-Regas 1986; Diabaté 1989), one the most accurate as shown by several authors (Grüter et al 1986; Raschke et al. 1991). It was simple enough to widely disseminate in the world (Diabaté et al. 1988a b, 1989; Wald et al. 1992). It became popular and several modifications were proposed (Moussu et al. 1989; Obrecht 1990; Zelenka et al. 1992, 1999; Beyer et al. 1996; Fontoynont et al. 1997; Iehlé et al. 1997; Ineichen, Perez 1999).

There are several empirical parameters in the method Heliosat-1, especially in the computation of the apparent albedoes of the ground and clouds and normalization of the digital counts. The relationship between the cloud index and the clearness index is empirically defined and its parameters are computed by the means of a comparison between the cloud index and measurements made by meteorological stations in the area under concern. All these parameters were well tuned during the construction of the method or of its varieties using ground-based measurements and this explains the good results attained by the authors. Table 1 gives the root mean square error (RMSE) reported by authors having developed a variety of the Heliosat-1 method and using measurements for tuning parameters (Rigollier, 2000). In all cases, adjustment is made with a null bias. The errors are obtained by subtracting satellite-derived assessments from ground measurements performed in the meteorological network at a coincident location and coincident time. 


\begin{tabular}{cccc}
\hline Type & Period & RMSE & Comments \\
\hline \multirow{4}{*}{ Hourly irradiation } & May 1979 & $120(16 \%)$ & Cano (1982), France \\
\cline { 2 - 3 } & Year 1983 & $92(10 \%)$ & \multirow{2}{*}{ Michaud-Regas (1986), France } \\
\cline { 2 - 3 } & Year 1984 & $98(16 \%)$ & \\
\cline { 2 - 4 } & Year 1983 & $64(7 \%)$ & Diabaté et al. (1988a), France \\
\cline { 2 - 4 } & May-June 1993 & $95(\mathrm{~N} / \mathrm{A})$ & Beyer et al. (1996), Germany \\
\cline { 2 - 4 } & June-July 1996 & $58(9 \%)$ & Dribssa et al. (1999), Italy \\
\hline \multirow{2}{*}{ Daily irradiation } & Years 1983-1985 & $\sim 370(11 \%)$ & Diabaté (1989), France \\
\cline { 2 - 4 } & Years 1994-1996 & N/A (4-8\%) & Sidrach de Cardona et al. (2002), Spain \\
\hline
\end{tabular}

Table 1. Errors (RMSE, in Wh $\mathrm{m}^{-2}$ ) reported by authors having developed a method using the Heliosat-1 principles. N/A: Not Available

However, when applied to other areas, or other periods, the accuracy, expressed as bias and RMSE in percentage of the mean irradiation, is usually lower than claimed by the inventors (Table 2). For example, one may note that the biases are not negligible in many cases. One may also remark in the first two rows that the biases found by Diabaté for two different periods over the same area differ largely: -7 \% in 1983 and -1\% for 1984 and 1985. Using the same parameters than Diabaté, Obrecht and Raschke found biases in monthly means of daily irradiation that range from -8 to $-29 \%$ for various parts of Sahel. This table clearly shows that modifications of the method Heliosat-1 are necessary to ensure that any correct implementation should lead to similar performances.

\begin{tabular}{|c|c|c|c|}
\hline Type & Reference & Bias & $R M S E$ \\
\hline \multirow{7}{*}{ Hourly irradiation } & Diabaté (1989) (France, year 1983) & $-7 \%$ & $14 \%$ \\
\hline & Diabaté (1989) (France, years 1984 and 1985) & $-1 \%$ & $18 \%$ \\
\hline & $\begin{array}{l}\text { Satel-Light project (CEC, DG 12) (various versions - } 3 \text { independent } \\
\text { assessments per version) (Fontoynont et al. 1997) }\end{array}$ & $\sim 10 \%$ & $\sim 30 \%$ \\
\hline & Zelenka et al. (1999) (Europe, Heliosat-1/Zelenka) & $1 \%$ & $23 \%$ \\
\hline & Hammer (2000) (Germany, Heliosat-1/EHF) & $5 \%$ & $30 \%$ \\
\hline & Olseth, Skarveit (2001) (Bergen, Norway, 1996-1997, Heliosat-1/EHF) & $1 \%$ & $25 \%$ \\
\hline & $\begin{array}{l}\text { Dumortier (2003) (one site in France, 1/2 hour, 1986-2000, Heliosat- } \\
\text { 1/EHF) }\end{array}$ & $1 \%$ & $21 \%$ \\
\hline \multirow{6}{*}{ Daily irradiation } & Obrecht (1990) (Sahel, June 1984) & $-2 \%$ & $9 \%$ \\
\hline & Zelenka et al. (1992) (Heliosat-1/Zelenka) & $-10 \%$ & $16 \%$ \\
\hline & Perez et al. (2002) (USA, 1999, Heliosat-1/Zelenka) & $-1 \%$ & $16 \%$ \\
\hline & Hammer (2000) (Germany, Heliosat-1/EHF) & $5 \%$ & $16 \%$ \\
\hline & Dumortier (2003) (Lyon, France, 1/2 hour, 1986-2000, Heliosat-1/EHF) & $2 \%$ & $9 \%$ \\
\hline & Beyer (pers. communication, Brazil, GOES satellite) & $\sim 3 \%$ & $\sim 14 \%$ \\
\hline \multirow{2}{*}{$\begin{array}{l}\text { Monthly mean of } \\
\text { hourly irradiation }\end{array}$} & Heidt et al. (1998) (Germany) & N/A & $19 \%$ \\
\hline & Diabaté (1989) (France) & N/A & $10 \%$ \\
\hline \multirow{6}{*}{$\begin{array}{l}\text { Monthly mean of } \\
\text { daily irradiation }\end{array}$} & Obrecht (1990) (Burkina-Fasso, year 1985) & $-29 \%$ & N/A \\
\hline & Obrecht (1990) (Senegal, year 1986) & $-9 \%$ & $10 \%$ \\
\hline & Solar Radiation Atlas of Africa (Heliosat) (Raschke et al. 1991) & $-8 \%$ & $10 \%$ \\
\hline & Heidt et al. (1998) & N/A & $10 \%$ \\
\hline & Petrarca et al. (1999) (Italy, 1994-1997) & N/A & $7 \%$ \\
\hline & Hammer (2000) (Germany, Heliosat-1/EHF) & $5 \%$ & $8 \%$ \\
\hline
\end{tabular}

The purpose of the present paper is to present a new version, called Heliosat-2, which integrates the knowledge gained by these various exploitations of the original method and its varieties in a coherent and thorough way. 
The various empirical parameters present in the method Heliosat-1 are now expressed using physical laws and there is no need for coincident pyranometric measurements to tune these parameters. The major motivations for creating this new version were to improve the capabilities of the method to process any type of data taken in the broadband visible range by geostationary meteorological satellites, including large time-series of images taken by different sensors, and to improve the implementation of the method by reducing the number of empirical parameters.

\section{THE NEW METHOD HELIOSAT-2}

Given the good fundamentals of the method Heliosat-1, it was decided to keep it principle, that is the construction of a "cloud index" resulting from a comparison of what is observed by the sensor to what should be observed over that pixel if the sky were clear, which is related to the "clearness" of the atmosphere. Actually, this principle is commonly adopted when the only inputs are images taken in the visible broad range (Pastre, 1981; Möser, Raschke, 1983, 1984; Cano et al. 1986; Stuhlmann et al. 1990; Delorme et al. 1992; Colle et al. 1999). Inputs to the method Heliosat-2 are not numerical counts of the satellite image, like in Heliosat-1. These counts are calibrated and thus converted into radiances $L$, in $\mathrm{W} \mathrm{m}^{-2} \mathrm{sr}^{-1}$. This permits to take into account the change of sensor, gain and calibration in a time-series. Hence, large time-series spanning over several changes of sensors and satellites may be processed, enhancing the interest of the Heliosat method in climatology. It also contributes to reduce drastically the number of empirical parameters since many of them would now be expressed using known physical laws and parameters. For the Meteosat data, we adopted the calibration coefficients proposed by Rigollier et al. (2002) and available on the Web site www.helioclim.net.

\subsection{The cloud index}

The cloud index $\mathrm{n}^{\mathrm{t}}(\mathrm{i}, \mathrm{j})$ is defined at instant $t$ and for pixel $(i, j)$ as:

$$
\left.n^{t}(i, j)=\left[\rho^{t}(i, j)-\rho_{g}^{t}(i, j)\right] /\left[\rho_{\text {cloud }}^{t}-\rho_{g}^{t}(i, j)\right)\right]
$$

In this equation, $\rho^{t}(i, j)$ is the reflectance, or apparent albedo, observed by the spaceborne sensor for the time $t$ and the pixel $(i, j): \rho^{t}(i, j)=\rho^{t}(i, j)=\pi L^{t}(i, j) / I_{0 m e t} \varepsilon(t) \cos \theta_{S}(t, i, j)$, where $L^{t}(i, j)$ is the observed radiance, $\theta_{S}$ is the sun zenithal angle, and $I_{0 m e t}$ is the total irradiance in the visible channel for the various Meteosat sensors (Rigollier et al. 2002). $\rho_{\text {cloud }}^{t}(i, j)$ is the apparent albedo of the brightest clouds, and $\rho_{g}^{t}(i, j)$ is the apparent albedo of the ground under clear skies. 
Iehlé et al. (1997) and Rigollier (2000) showed the importance of the model used for modeling the clear-sky irradiation. Using different models, these authors found discrepancies larger than $200 \mathrm{Wh} \mathrm{m}^{-2}$ between the retrieved values of hourly global irradiation. The clearer the skies, the larger the discrepancies. Following the conclusions of Rigollier et al. (2000), we adopt the clear sky models of the 4th European Solar Radiation Atlas (ESRA 2000). The ESRA proposes two sets of models, each providing the global value $G$ and the beam and diffuse components. One is best suited for the assessment of the irradiance. The other should be preferred for the computation of hourly irradiation and daily sum of irradiation. For the sake of conciseness, we direct the reader to the ESRA (2000) or Rigollier et al. (2000) for the detailed description of these models and their equations. This should be completed by the revision proposed by J. Page and J. Remund and reported in Geiger et al. (2002). The inputs to these models are the Linke turbidity factor for an air mass of $2, T_{L}(A M 2)$, and the elevation of the site, besides the parameters related to the solar geometry.

The reflectance observed by the sensor $\rho^{t}$ under clear skies is a function of $\rho_{g}^{t}, \theta_{S}$, the satellite zenithal angle $\theta_{v}$, and the difference, $\psi$, of the sun and satellite azimutal angles. At the first order, given the large size of the pixel (> $1 \mathrm{~km}$ ), the multiple reflection and scattering effects are negligible and we can write (Tanré et al. 1990):

$$
\rho^{t}(i, j)=\rho_{a t m}^{t}\left(\theta_{S}, \theta_{v}, \psi\right)+\rho_{g}^{t}(i, j) T^{t}\left(\theta_{S}\right) T^{t}\left(\theta_{v}\right)
$$

where $\rho_{a t m}^{t}\left(\theta_{S}, \theta_{v}, \psi\right)$ is the intrinsic reflectance of the atmosphere, $T^{t}\left(\theta_{S}\right)$ and $T^{t}\left(\theta_{v}\right)$ are the global transmittances of the atmosphere for respectively the incident and upward radiation.

The intrinsic reflectance of the atmosphere, also called the path reflectance, is caused by the scattering of the incident and upward radiation towards the sensor. If the scattering by the atmosphere is isotropic and homogeneous, it is conceivable that the path radiance $L_{a t m}$ reaching the sensor can be modeled in the same way than the path radiance reaching the ground. This was checked by Rigollier (2000) by the means of numerical simulations of the radiative transfer in the atmosphere. $L_{\text {atm }}$ can be expressed using the expression of the diffuse irradiance under clear sky at ground level, $D_{c}$, obtained by the ESRA model:

$$
L_{a t m}=\left(D_{c} / \pi\right)\left(I_{0 m e t} / I_{0}\right)\left(<\cos \theta_{V}>/ \cos \theta_{V}\right)^{0,8}
$$

The factor $\pi$ permits to convert an irradiance $\mathrm{D}$ into radiance. The ratio $\left(I_{\text {omet }} / I_{0}\right)$ normalizes the extraterrestrial irradiance $I_{0}$ to the Meteosat sensor case. Following Beyer et al. (1996), the ratio $\left(\left\langle\cos \theta_{V}\right\rangle / \cos \theta_{V}\right)^{0,8}$ empirically corrects for the satellite zenithal angle without bias $\left(\left\langle\cos \theta_{V}\right\rangle=0.5\right)$.

The global transmittance of the atmosphere $T^{t}$ is the sum of the direct (or beam), $\operatorname{Tr}_{B}$, and diffuse, $\operatorname{Tr}_{D}$, transmittances that can be expressed by the means of the ESRA model as:

$$
\operatorname{Tr}_{B}\left(\theta_{S}\right)=\exp \left(-0.8662 T_{L}(A M 2) m \delta_{r}(m)\right)
$$




$$
\operatorname{Tr}_{D}\left(\theta_{S}\right)=T_{r d}\left(T_{L}(A M 2)\right) F_{d}\left(\theta_{S}, T_{L}(A M 2)\right)
$$

where $m$ is the air mass, $\delta_{r}(m)$ the integral Rayleigh optical thickness, $T_{r d}\left(T_{L}(A M 2)\right)$ is the transmittance at zenith and $F_{d}\left(\theta_{S}, T_{L}(A M 2)\right)$ the angular correction.

According to the principle of reciprocity, the formulations of the downward and upward transmittances are identical:

$$
\begin{aligned}
& T\left(\theta_{S}\right)=\operatorname{Tr}_{B}\left(\theta_{S}\right)+\operatorname{Tr}_{D}\left(\theta_{S}\right) \\
& T\left(\theta_{v}\right)=\operatorname{Tr}_{B}\left(\theta_{v}\right)+\operatorname{Tr}_{D}\left(\theta_{v}\right)
\end{aligned}
$$

\subsection{The apparent ground albedo $\rho_{g}$ and apparent cloud albedo $\rho_{\text {cloud }}$}

Using Equation 2, one may define a quantity $\rho^{* t}(i, j)$ that is a ground albedo if the sky were clear at the instant $t$.

$$
\rho^{* t}(i, j)=\left[\rho^{t}(i, j)-\rho_{a t m}\left(\theta_{S}, \theta_{v}, \psi\right)\right] / T\left(\theta_{S}\right) T\left(\theta_{v}\right)
$$

The ground albedo $\rho_{g}{ }^{t}(i, j)$ is in principle the minimum value in a time-series of $\rho^{* t}(i, j)$ since it is assumed that the presence of a cloud increases the apparent albedo. However, some artifacts should be eliminated. The analysis of several years of images from Meteosat shows that it happens in day time that some pixels exhibit very low radiances $L^{t}(i, j)$, similar to those observed during the night, while the sun is well above the horizon. A constraint is imposed to avoid such cases; the radiance should be greater than 3 percent of the maximal radiance that can be observed by the sensor:

$$
L^{t}(i, j) \geq 0.03 I_{\text {omer }}(t) / \pi+b(t)
$$

where $b(t)$ is the calibration coefficient, and more exactly the radiance measured when viewing darkness (Rigollier et al. 2002).

The time series of $\rho^{* t}(i, j)$ is restricted to the instants for which $\theta_{S}$ is less than the maximum of $50^{\circ}$ and $\left(2 \theta_{S}^{\text {noon }} /\right.$ 3 ), where $\theta_{S}{ }^{\text {noon }}$ is the angle observed at noon, remembering that $\theta_{S}$ is less than $75^{\circ}$ in any case. Once the time series established, the first and second minima are searched. The absolute minimum is subject to undetected defects in the original image and is more variable than the second minimum. Therefore, we set the ground albedo $\rho_{g}(i, j)$ for this period to the second minimum.

The period of the time-series should be the shortest as possible in order to take into account the rapid variations of the ground albedo, if any. In a real-time operational mode, a moving period may be adopted. Compared to the method Heliosat-1, wherein it is preferable to have one estimate of the ground albedo per slot (i.e., the instants of acquisition by the sensor), the accurate correction of the effects of the sun and satellite angles permits to merge 
all the slots into the time-series. Thus, the period may be shortened. There is only one map of $\rho_{g}$ and this map may be used for all slots. Note that Equation 2 assumes that the ground is of Lambertian nature, i.e. the reflectance does not depend on $\theta_{S}, \theta_{V}$ and $\psi$. Vermote et al. (1994) propose several bi-directional models to consider these effects. Following Hammer (2000) or Perez et al. (2002), defining $\rho_{g}$ for each slot is a mean to take into account the non-Lambertian nature. Such elements may be accommodated into the method Heliosat-2. The retrieved ground albedo is actually a ground albedo and not an approximate quantity like in Heliosat-1. This permits on the one hand to perform checking and monitoring of the method, even on an operational basis. On the second hand, it helps in solving the problem of the constant cloud cover over a pixel or a group of pixel. In that case, the minimal value will correspond to a cloudy instant. Using external knowledge of the expected albedo together with image processing techniques applied to the time-series of the checked ground albedoes, one may detect such cases and compute the likely value.

Solutions were proposed to tackle the case of the appearance of snow (Zelenka 2001, 2003) or the specular reflection on the sun on ground (Perez et al. 2002). They may be introduced in the method Heliosat-2. The specular reflection on the ocean is dealt with by Lefèvre et al. (2002) within the method Heliosat-2.

The apparent albedo of the clouds $\rho_{\text {cloud }}$ is defined by Cano (1982) as the typical value for the brightest clouds. The effective cloud albedo $\rho_{\text {eff }}$ depends upon the sun zenithal angle. We derive the following model from the drawings in Taylor, Stowe (1984a):

$$
\rho_{e f f}^{t}(i, j)=0.78-0.13\left[1-\exp \left(-4 \cos \left(\theta_{S}\right)^{5}\right]\right.
$$

The parameter $\rho_{\text {cloud }}$ is to be compared to the quantities $\rho^{* t}(i, j)$ to compute the cloud index $n$ : $\rho_{\text {cloud }}$ is not an actual albedo of cloud. For $\rho^{*^{t}}(i, j)=\rho_{\text {cloud }}^{t}(i, j)$, the cloud index $n$ should be equal to unity. Following Equation 6 , we define the apparent cloud albedo $\rho_{\text {cloud }}^{t}(i, j)$ as:

$$
\rho_{\text {cloud }}^{t}(i, j)=\left[\rho_{\text {eff }}^{t}(i, j)-\rho_{\text {atm }}^{t}\left(\theta_{S}, \theta_{v}, \psi\right)\right] / T\left(\theta_{S}\right) T\left(\theta_{v}\right)
$$

Two constraints are added, gained from Bauer (1996) and our own experience:

$$
\begin{aligned}
& \rho_{\text {cloud }}^{t}(i, j)>0.2 \text {, otherwise } \rho_{\text {cloud }}^{t}(i, j)=0.2 \\
& \text { and } \rho_{\text {cloud }}^{t}(i, j)<2.24 \rho_{\text {eff }}(i, j) \text {, otherwise } \rho_{\text {cloud }}^{t}(i, j)=2.24 \rho_{\text {eff }}^{t}(i, j)
\end{aligned}
$$

The value 2.24 is the largest anisotropy factor observed by Taylor, Stowe (1984b) for the present geometrical configuration sun-pixel-sensor and thick water cloud. 


\subsection{Computing the hourly and daily irradiation}

The clear-sky index $K_{c h}$ is equal to the ratio of the hourly global irradiation at ground on a horizontal surface $G_{h}$ to the same quantity but for clear skies $G_{c h}$ :

$$
K_{c h}=G_{h} / G_{c h}
$$

Rigollier and Wald (1998) propose the following relationship between $n$ and $K_{c h}$ :

$$
\begin{aligned}
n^{t}<-0.2 \quad K_{c h} & =1.2 \\
-0.2<n^{t} & <0.8 \quad K_{c h}=1-n \\
0.8<n^{t}<1.1 \quad K_{c h} & =2.0667-3.6667 n^{t}+1.6667\left(n^{t}\right)^{2} \\
n^{t} & >1.1 \quad K_{c h}=0.05
\end{aligned}
$$

This Equation was introduced in the version Heliosat-1/EHF and led to satisfactory results (Hammer 2000). Thus, we also use this relationship in Heliosat-2.

The global daily irradiation $G_{d}(i, j)$ is computed from the set of hourly irradiations available for that day. The larger the number of images used per day, the lower the level of error. We use the model of Raschke et al. (1991) but applied to the clear-sky index instead of the clearness index. Let denote the horizontal daily irradiation for clear sky by $G_{c d}(i, j)$ and the daily clear-sky index by $K_{c d}(i, j)$. $G_{d}(i, j)$ is then computed from the $N$ assessments of the hourly irradiation $G_{h}(i, j)$ made during the day:

$$
G_{d}(i, j)=K_{c d}(i, j) G_{c d}(i, j)=G_{c d}(i, j) \sum_{I}^{N} w_{h} K_{c h}(i, j)
$$

where $w_{h}=G_{c h}(i, j) / \sum_{I}^{N} G_{c h}(i, j)$

It comes

$$
G_{d}(i, j)=G_{c d}(i, j) \sum_{I}^{N} G_{h}(i, j) / \sum_{I}^{N} G_{c h}(i, j)
$$

For each hour $h$ in the summation, the mean solar elevation for this hour should be greater than $15^{\circ}$ for the clearsky model to be valid.

\section{COMPARISON BETWEEN RETRIEVED VALUES AND STATION MEASUREMENTS}

Similarly to previous works, hourly and daily irradiations derived from satellite are compared to measurements performed at ground level by pyranometers in meteorological stations (Table 3). The 35 stations were selected in flat areas, in order to avoid the specific errors encountered in mountainous areas. We only used measurements of 
hourly irradiation greater than $10 \mathrm{Wh} \mathrm{m}^{-2}$, a value typical of the diffuse hourly irradiation for the sunset and sunrise under clear-sky at $60^{\circ} \mathrm{N}$. For these hours of very low solar elevation, the measured irradiation is mainly of diffuse nature and is influenced by local conditions, including orography and the presence of nearby obstacles. By removing these values, we ensure better conditions for understanding the results.

\begin{tabular}{|c|c|c|c|c|c|}
\hline Station name & WMO id. & Latitude & Longitude & Altitude & Country \\
\hline Aviemore & 03063 & 57.20 & -3.83 & 220 & United Kingdom \\
\hline Eskdalemuir & 03162 & 55.32 & -3.20 & 242 & United Kingdom \\
\hline Easthampstead / Bracknell & 03763 & 51.38 & -0.78 & 73 & United Kingdom \\
\hline Melle & 06430 & 50.98 & 3.83 & 17 & Belgium \\
\hline Uccle & 06447 & 50.80 & 4.35 & 100 & Belgium \\
\hline St. Hubert & 06476 & 50.03 & 5.40 & 556 & Belgium \\
\hline Caen & 07027 & 49.18 & -0.45 & 78 & France \\
\hline St. Quentin & 07061 & 49.82 & 3.20 & 98 & France \\
\hline Reims & 07070 & 49.30 & 4.03 & 95 & France \\
\hline Bourges & 07255 & 47.07 & 2.37 & 161 & France \\
\hline Macon & 07385 & 46.30 & 4.80 & 221 & France \\
\hline Limoges & 07434 & 45.87 & 1.18 & 396 & France \\
\hline Carcassonne & 07635 & 43.22 & 2.32 & 130 & France \\
\hline Perpignan & 07747 & 42.73 & 2.87 & 43 & France \\
\hline Valladolid & 08141 & 41.65 & -4.77 & 734 & Spain \\
\hline Hamburg - Sasel & 10141 & 53.65 & 10.12 & 49 & Germany \\
\hline Bremen & 10224 & 53.05 & 8.80 & 24 & Germany \\
\hline Seehausen & 10261 & 52.90 & 11.73 & 21 & Germany \\
\hline Neubrandenburg & 10280 & 53.55 & 13.20 & 73 & Germany \\
\hline Osnabrueck & 10317 & 52.25 & 8.05 & 104 & Germany \\
\hline Braunschweig & 10348 & 52.30 & 10.45 & 83 & Germany \\
\hline Potsdam & 10378 & 52.37 & 13.08 & 107 & Germany \\
\hline Bocholt & 10406 & 51.83 & 6.53 & 24 & Germany \\
\hline Kassel & 10438 & 51.30 & 9.45 & 237 & Germany \\
\hline Dresden - Wahnsdorf & 10486 & 51.12 & 13.68 & 246 & Germany \\
\hline Bonn - Friesdorf & 10517 & 50.70 & 7.15 & 65 & Germany \\
\hline Weimar & 10555 & 50.98 & 11.32 & 275 & Germany \\
\hline Trier & 10609 & 49.75 & 6.67 & 278 & Germany \\
\hline Wuerzburg & 10655 & 49.77 & 9.97 & 275 & Germany \\
\hline Coburg & 10671 & 50.28 & 10.98 & 331 & Germany \\
\hline Saarbruecken & 10708 & 49.22 & 7.12 & 325 & Germany \\
\hline Stuttgart & 10739 & 48.83 & 9.20 & 318 & Germany \\
\hline Nuernberg & 10763 & 49.50 & 11.08 & 312 & Germany \\
\hline Weihenstephan & 10863 & 48.40 & 11.70 & 472 & Germany \\
\hline Budapest / Lorinc & 12843 & 47.43 & 19.18 & 138 & Hungary \\
\hline
\end{tabular}

Table 3. List of stations used for the comparison

The satellite data are high resolution images covering Europe and brought to the infrared resolution, that is $5 \mathrm{~km}$ at nadir. They are available every half-hour, between 0800 and 1500 UTC, from July 1994 to June 1995. We used only the images acquired for even slots $(2,4 \ldots)$. Only the instants for which the sun elevation is greater than $15^{\circ}$, were kept for the comparison, as it has been said that the description of the physical processes is not valid below that limit. The Linke turbidity factors are those of Angles et al. (1998, 1999).

Three months were used for the comparison: January 1995, April 1995 and July 1994. The estimate of the daily irradiation is said valid if at least 5 hourly irradiations are used in the computation in January and April and 8 in July. Note that the limited period for which satellite images are available every day and its asymmetry with 
respect to the local noon for our stations that are mostly located East of the longitude $0^{\circ}$, leads to bias in the retrieved daily irradiation, since the morning hours are more numerous than those in the afternoon. This is a limitation of our validation.

Most of the published works average the individual satellite assessments on a block of pixels centered on the location of the pyranometer. The size of this block has a strong influence on the comparison (Pinker, Laszlo 1991). Several other attempts, not published in international journals, found similar conclusions and demonstrated that there is not a unique size of pixel aggregate giving the best results. It is possible at one time to get better agreement with one size and at other times better agreement with a different size. Beyer et al. (1992) suggested that the local variance might be used as a measure of the spatial heterogeneity and may serve to determine the most appropriate size. Nevertheless, experience shows that compared to a single pixel, averaging over a block decrease the error significantly. Contrary to the other works, we are using a single pixel. The reason to do so is to obtain assessments of the accuracy that are independent upon the size of the aggregate.

Given the two time-series, we compute the difference (measured - estimated):

- for hourly irradiation for a given month, for all the hours, and for the monthly mean of hourly irradiation for a given hour, for all hours,

- for daily irradiation for a given month, for all the days, and for the monthly mean of daily irradiation,

- for the cumulative of the daily irradiation during 5 days and 10 days.

For the monthly means and sums of daily irradiation, we kept only the values that are made from at least $60 \%$ of valid estimates. The differences have been computed and are summarized in Table 4 by the bias, RMSE and correlation coefficient for all stations together. 


\begin{tabular}{|c|c|c|c|c|c|c|}
\hline Information type & Month & Mean value & Bias & RMSE & $\begin{array}{l}\text { Correlation } \\
\text { coefficient }\end{array}$ & $\begin{array}{l}\text { Number of } \\
\text { observations }\end{array}$ \\
\hline \multirow{3}{*}{ Hourly irradiation } & Jan 95 & 137 & $-31(-23 \%)$ & $62(45 \%)$ & 0.83 & 5028 \\
\hline & Apr 95 & 361 & $2(0 \%)$ & $96(27 \%)$ & 0.90 & 8248 \\
\hline & Jul 94 & 569 & $1(0 \%)$ & $103(18 \%)$ & 0.87 & 8105 \\
\hline \multirow{3}{*}{$\begin{array}{l}\text { Monthly mean of hourly } \\
\text { irradiation }\end{array}$} & Jan 95 & 142 & $-33(-23 \%)$ & $41(29 \%)$ & 0.91 & 160 \\
\hline & Apr 95 & 361 & $1(0 \%)$ & $41(11 \%)$ & 0.94 & 280 \\
\hline & Jul 94 & 568 & $1(0 \%)$ & $48(8 \%)$ & 0.93 & 272 \\
\hline \multirow{3}{*}{ Daily irradiation } & Jan 95 & 987 & $-54(-5 \%)$ & $199(20 \%)$ & 0.95 & 344 \\
\hline & Apr 95 & 3366 & $175(5 \%)$ & $534(16 \%)$ & 0.95 & 1044 \\
\hline & Jul 94 & 5817 & $143(2 \%)$ & $566(10 \%)$ & 0.94 & 887 \\
\hline \multirow{3}{*}{$\begin{array}{l}\text { Monthly mean of daily } \\
\text { irradiation }\end{array}$} & Jan 95 & 891 & $-128(-14 \%)$ & $215(24 \%)$ & 0.88 & 20 \\
\hline & Apr 95 & 3367 & $175(5 \%)$ & $243(7 \%)$ & 0.97 & 35 \\
\hline & Jul 94 & 5776 & $192(3 \%)$ & $307(5 \%)$ & 0.92 & 34 \\
\hline \multirow{3}{*}{$\begin{array}{l}\text { 5-days irradiation (at } \\
\text { least } 60 \% \text { of valid days) }\end{array}$} & Jan 95 & 4607 & $-333(-7 \%)$ & $898(19 \%)$ & 0.94 & 75 \\
\hline & Apr 95 & 16826 & $878(5 \%)$ & $1794(11 \%)$ & 0.96 & 209 \\
\hline & Jul 94 & 28736 & $1151(4 \%)$ & $2419(8 \%)$ & 0.91 & 202 \\
\hline \multirow{3}{*}{$\begin{array}{l}\text { 10-days irradiation (at } \\
\text { least } 60 \% \text { of valid days) }\end{array}$} & Jan 95 & 8788 & $-742(-8 \%)$ & $1836(21 \%)$ & 0.93 & 43 \\
\hline & Apr 95 & 33675 & $1773(5 \%)$ & $3285(10 \%)$ & 0.96 & 104 \\
\hline & Jul 94 & 57680 & $2021(4 \%)$ & $3454(6 \%)$ & 0.92 & 101 \\
\hline
\end{tabular}

Table 4. Differences between measured and estimated values in $\mathrm{Wh} \mathrm{m}^{-2}$. The mean value is that of the ground measurements. The percentages are expressed relatively to this mean value.

The number of observations is large enough, except for the assessment of the monthly mean of daily irradiation in January, where only 20 stations are retained. This may explain why the bias for the mean value (-128) is larger in absolute value than that for the single values $(-54)$.

The bias is negative in January for both hours and days. It is positive in April and July. For these months, the fact that the bias is not equal to 0 for daily values while it is for hourly values may be explained by the limited period of available images as discussed above. The bias may be large in relative values in January (-23\%); it indicates that Heliosat-2 overestimates the hourly irradiation for low sun elevations. In addition, one should note that $T_{L}(A M 2)$ influences the bias. As we use typical values of $T_{L}(A M 2)$ for each site and each month, the discrepancies between these values and the actual values lead to errors in assessing mean values of the irradiation. We performed the method Heliosat-2 on the same data but using different $T_{L}(A M 2)$. We found that the bias was sensitive to the selected value of $T_{L}(A M 2)$, the larger discrepancies being found when the sun is low. The correlation coefficient is high in all cases, the lowest values being observed in January. The RMSE is not constant and increases with the mean value. In relative value, it is the largest in winter (45\% for hourly irradiation) and the smallest in July (18\%). Considering that using a block of 3 per 3 pixels would lead to a decrease of the standard-deviation by 3, thus decreasing the RMSE, we estimate the corresponding relative RMSE as 26, 9 and 6\% for January, April and July instead of 45, 27 and 18\% reported in Table 4 for hourly irradiation. For daily irradiation, the relative RMSE would be 8,7 and $4 \%$ instead of 20,16 and $10 \%$. One notes that these values are close to those in Table 1. 


\section{CONCLUSION}

The method Heliosat-2 meets the objectives set up before its development. It is more physically sound than the previous one. All parameters that needed to be tuned for each implementation of the method Heliosat-1 have been removed, set up to constant values, or automatically determined. No ground measurement is used for the development, contrary to the method Heliosat-1 and others. This should ensure a worldwide application of the method Heliosat-2.

The first comparison with ground measurements shows errors that are similar to those reported for Heliosat-1. Further investigations should be performed to better understand the performances and the limitations of Heliosat2, especially for low sun elevations, and therefore bring possible improvements.

The method Heliosat-2 has the capabilities to process any type of data from geostationary meteorological satellites, including large time-series of images taken by different sensors. It is applicable in real-time or on archives of images, whatever their resolution. By suppressing empirically defined parameters, the implementation is the same for all cases. It facilitates exchange of knowledge and further collective improvements of the method Heliosat-2. Software is freely available at www.helioclim.net. Routines are written in $\mathrm{C}$ and documented. They permit to implement the method Heliosat-2 (Lefèvre et al. 2002).

The method Heliosat-2, as well as all other known methods, cannot perform accurately in areas where the scales of variability of the irradiation are smaller than 2-5 times the size of the pixel. This holds for the mountainous areas, for example.

The gains in accuracy obtained relative to the method Heliosat-1 are not coming from an increase of the dimensionality of the inputs originating from the satellite images, which remain the same. They come from external knowledge: the elevation and the Linke turbidity factor for each pixel of the area to process and some properties of the sensor for the day under concern. The value of the Linke turbidity factor is of primary importance in the method Heliosat-2 since it governs the clear-sky irradiation. It may be a problem, since it is known for a limited number of sites. Some empirical laws help in assessing a value for any place in the world. Remund et al. (2003) report on the creation of a database covering the whole world, available at www.sodais.com. Several databases of terrain elevation are available in gridded format depending upon the requested size of the cell. The most known databases are ETOPO5 (5' of arc angle) and GTOPO30 (30" of arc angle) which are covering the whole world. 
The method Heliosat-2 may be improved in several points. The clear-sky model does not take into account the diffuse part of the radiation that has been reflected once or more by the ground before impinging on the site under concern. It is known from previous works that this has a little impact for high sun elevations and large size of pixels. In any other cases, low sun elevation or pixel size smaller than approximately $1 \mathrm{~km}$, this physical process should be taken into account (Tanré et al. 1990). This implies a modification of the model and the knowledge of the surrounding albedoes, including their bi-directional properties. It would help in solving the problem of the sun elevations less than $15^{\circ}$. Another major point of improvement is likely the relationship between the clear sky index and the cloud index (Equation 12). Gains will be reached if overcast skies may be better modeled.

The snow covering periodically the ground as well as permanent cloud coverage over a site creates problems in preventing from accurate determining the apparent ground albedo. Another source of information is necessary for the daily knowledge of the snow coverage; this is available in certain areas. Zelenka $(2001,2003)$ developed a promising method based on the observation of the time-series of apparent albedo. As for the permanent cloud coverage, one may use a climatological knowledge of the typical ground albedoes that would be observed without the clouds. These drawbacks were present in the method Heliosat-1.

\section{ACKNOWLEDGEMENTS}

We are grateful to Hans-Georg Beyer, Dominique Dumortier, Gerhard Gesell, Annette Hammer, Detlev Heinemann, Pierre Ineichen, John Page, Christian Perrin de Brichambaut, Richard Perez, Corrado Ratto, Christian Reise, Antoine Zelenka for the numerous discussions we had on the method Heliosat and its various improvements. We thank the two referees for their help in clarifying the content of the paper. The meteorological offices from France, Germany, Hungary, Spain, The Netherlands and United Kingdom have kindly provided the measurements of global irradiation at no or low cost. They are thanked for their support. The high resolution Meteosat data were kindly provided by the European Space Agency (ESOC). We especially thank Jean Le Ber. This work was partly supported by the European Commission, under the Information Society Technology Programme, IST-1999-12245. 


\section{REFERENCES}

Angles, J., Menard, L., Bauer, O., Wald, L., 1998. A Web server for accessing a database on solar radiation parameters. In Proceedings of the Earth Observation \& Geo-Spatial Web and Internet Workshop '98, Josef Strobl \& Clive Best Eds., Salzburger Geographische Materialien, Universität Salzburg, Salzburg, Austria, Heft 27, 33-34.

Angles, J., Menard, L., Bauer, O., Rigollier, C., Wald, L., 1999. A climatological database of the Linke turbidity factor. In Proceedings of the ISES Solar World Congress 1999, Jerusalem, Israel, July 4-9, 1999, volume I, $432-434$.

Bauer, O., 1996. Les échanges océan-atmosphère dans l'Atlantique subtropical nord-est : apports de Meteosat. Thèse de Doctorat, Université de Nice - Sophia Antipolis, 162 p.

Beyer, H. G., Reise, C., Wald L., 1992. Utilization of satellite data for the assessment of large scale PV grid integration. In Proceedings of 11th Photovoltaic Solar Energy Conference, pp. 1309-1312, Hardwood Academic Publ., Switzerland.

Beyer, H.G., Costanzo, C., Heinemann, D., 1996. Modifications of the Heliosat procedure for irradiance estimates from satellite images. Solar Energy, 56, 207-212.

Cano, D., 1982. Etude de l'ennuagement par analyse de séquences d'images de satellite. Application à l'évaluation du rayonnement solaire global au sol. Thèse de Doctorat, École Nationale Supérieure des Télécommunications, Paris, France.

Cano, D., Monget, J.-M., Albuisson, M., Guillard, H., Regas, N., Wald, L., 1986. A method for the determination of the global solar radiation from meteorological satellite data. Solar Energy, 37, 31-39.

Colle, S., Luna de Abreu, S., Couto, P., Mantelli, S., 1999. Distribution of solar irradiation in Brazil derived from geostationary satellite data. In Proceedings of the Solar World Congress ISES 1999 (CD-ROM), Jerusalem, July 4-9 1999.

Delorme, C., Gallo, A., Olivieri, J., 1992. Quick use of Wefax images from Meteosat to determine daily solar radiation in France. Solar Energy, 49, 191-197.

Diabaté, L., 1989. Détermination du rayonnement solaire à l'aide d'images satellitaires. Thèse de Doctorat en Sciences, École Nationale Supérieure des Mines de Paris, Paris, France.

Diabaté, L., Demarcq, H., Michaud-Regas, N., Wald, L., 1988a. Estimating incident solar radiation at the surface from images of the Earth transmitted by geostationary satellites: the Heliosat Project. International Journal of Solar Energy, 5, 261-278. 
Diabaté L., Moussu G., Wald L. 1988b, An operational tool for the fine-scale mapping of the incident solar radiation using satellite images : the Heliosat station. In : Proceedings of the 1988 annual meeting of the American Solar Energy Society, pp. 11-17.

Dribssa, E., Cogliani, E., Lavagno, E., Petrarca, S., 1999. A modification of the Heliosat method to improve its performance. Solar Energy, 65, 369-377.

Dumortier, D., 2003. Lumière naturelle et rayonnement solaire. Habilitation à Diriger les Recherches, HDR 2003011, 11 septembre 2003, INSA, Lyon, France, 149 p.

ESRA, European Solar Radiation Atlas, 2000. Fourth edition, includ. CD-ROM. Edited by J. Greif, K. Scharmer. Scientific advisors: R. Dogniaux, J. K. Page. Authors: L. Wald, M. Albuisson, G. Czeplak, B. Bourges, R. Aguiar, H. Lund, A. Joukoff, U. Terzenbach, H. G. Beyer, E. P. Borisenko. Published for the Commission of the European Communities by Presses de l'Ecole, Ecole des Mines de Paris, Paris, France.

Fontoynont, M., Dumortier, D., Heinemann, D., Hammer, A., Olseth, J.A., Skarveit, A., Ineichen, P., Reise, C., Page, J., Roche, L., Beyer, H.G., Wald, L., 1997. Satel-Light, Processing of Meteosat data for the production of high quality daylight and solar radiation data available on a World Wide Web Internet server. Mid-term progress report JOR3 - CT 95 - 0041, Project Satel-Light, for the Commission of the European Communities, Ecole Nationale des Travaux Publics de l'Etat, Vaulx-en-Velin, France.

Geiger, M., Diabaté, L., Ménard, L., Wald, L.. 2002. A web service for controlling the quality of measurements of global solar irradiation. Solar Energy, 73, 475-480.

Grüter, W., Guillard, H., Möser, W., Monget, J.-M., Palz, W., Raschke, E., Reinhardt, R.E., Schwarzmann, P., Wald, L., 1986. Solar Radiation Data from Satellite Images, Solar Energy R\&D in the European Community, Series F, Volume 4, D. Reidel Publishing Company, 100 p.

Hammer A., 2000. Amwendungsspezifische Solarstrahlungsinformationen aus Meteosat-Daten. PhD Thesis, Farbereich Physik, Carl von Ossietzky University, Oldenburg, Germany.

Heidt, F.D., Teichmann, C., Büchler, P., Schulze-Kegel, D., 1998. Satellite-based solar radiation data go Internet. In Proceedings of the second ISES-Europe Solar Congress, EuroSun'98.

Iehlé, A., Lefèvre, M., Bauer, O., Martinoli, M., Wald, L., 1997. Meteosat: A valuable tool for agrometeorology. Final report for the European Commission, Joint Research Centre, Ispra, Italy.

Ineichen, P., Perez, R., 1999. Derivation of cloud index from geostationary satellites and application to the production of solar irradiance and daylight illuminance data. Theoretical and Applied Climatology, 64, 119130. 
Lefèvre, M., Albuisson, M., Wald, L., 2002. Description of the software Heliosat-2 for the conversion of images acquired by Meteosat satellites in the visible band into maps of solar radiation available at ground level. Report available at www.helioclim.org/heliosat, $42 \mathrm{p}$.

Michaud-Regas, N., 1986. Mise en oeuvre et validation d'une méthode opérationnelle et automatique pour l'évaluation d'atlas solaires en Europe à l'aide de mesures satellitaires Meteosat. Thèse de Doctorat, Université Paris VII, Paris, France.

Möser, W., Raschke, E., 1983. Mapping of global radiation and of cloudiness from Meteosat image data: theory and ground truth comparisons. Meteorologische Rundschau, 36, 33-41.

Möser, W., Raschke, E., 1984. Incident solar radiation over Europe estimated from Meteosat data. Journal of Applied Meteorology, 23, 166-170.

Moussu, G., Diabaté, L., Obrecht, D., Wald, L., 1989. A method for the mapping of the apparent ground brightness using visible images from geostationary satellites. International Journal of Remote Sensing, 10, 1207-1225.

Obrecht, D.. 1990, Météorologie solaire et images satellitaires : cartographie du rayonnement solaire, détermination de l'albédo des sols et évaluation de l'ennuagement. Thèse de Doctorat en Sciences, Université de Nice- Sophia Antipolis, France.

Olseth, J.A., Skarveit, A., 2001. Solar irradiance, sunshine duration and daylight illuminance derived from Meteosat data for some European sites. Theoretical and Applied Climatology, 69, 239-252.

Pastre, C., 1981. Développement d'une méthode de détermination du rayonnement solaire global à partir des données Meteosat. La Météorologie, VI série N²4, mars 1981.

Perez, R., Seals, R., Zelenka, A., 1997. Comparing satellite remote sensing and ground network measurements for the production of site/time specific irradiance data. Solar Energy, 60, 89-96.

Perez, R., Ineichen, P., Moore, K., Kmiecik, M., Chain, C., George, R., Vignola, F., 2002. A new operational model for satellite-derived irradiances: description and validation. Solar Energy, 73, 307-317.

Petrarca, S., Spinelli, F., Cogliani, E., Mancini, M., 1999. La radiazione solare globale al suolo in Italia negli anni 1996-1997. Valori medi mensili stimati dalle immagini fornite dal satellite Meteosat, DEI srl Tipografia del Genio Civile, Rome, Italy.

Pinker, R. T., Laszlo, I., 1991. Effects of spatial sampling of satellite data on derived surface solar irradiance. Journal of Atmospheric and Oceanic Technology, 8, 96-107. 
Raschke, E., Stuhlmann, R., Palz, W., Steemers, T.C., 1991. Solar Radiation Atlas of Africa, A. Balkema, Rotterdam, The Netherlands, $155 \mathrm{p}$.

Remund, J., Wald, L., Lefevre, M., Ranchin, T., Page, J., 2003. Worldwide Linke turbidity information. In Proceedings of the ISES 2003, Goeteborg, Sweden, 16-19 June 2003.

Rigollier, C., 2000. Vers un accès à une climatologie du rayonnement solaire : estimation de l'irradiation globale à partir d'images satellitales. Thèse de Doctorat en Sciences et Technologies de l'Information et de la Communication, Université Nice - Sophia Antipolis, France, 194 p.

Rigollier, C., Wald, L., 1998. Using Meteosat images to map the solar radiation: improvements of the Heliosat method. In Proceedings of the $9^{\text {th }}$ Conference on Satellite Meteorology and Oceanography. Published by Eumetsat, Darmstadt, Germany, EUM P 22, pp. 432-433.

Rigollier, C., Bauer, O., Wald, L., 2000. On the clear sky model of the 4th European Solar Radiation Atlas with respect to the Heliosat method. Solar Energy, 68, 33-48.

Rigollier, C., Lefèvre, M., Blanc, Ph., Wald, L., 2002. The operational calibration of images taken in the visible channel of the Meteosat-series of satellites. Journal of Atmospheric and Oceanic Technology, 19, 1285-1293.

Sidrach de Cardona, M., Mora-López, L., Ramirez Santigosa, L., Marchante Jimenez, M., Navarro Fernández, A., 2002. Generación de años tipo de radiación global y de temperatura para su uso en el dimensionado de sistemas fotovoltaicos. In Proceedings of the International Forum on Renewable Energies, May 8-10, 2002, Tetuan, Morocco, pp. 153-158.

Stuhlmann, R., Rieland, M., Raschke, E., 1990. An improvement of the IGMK model to derive total and diffuse solar radiation at the surface from satellite data. Journal of Applied Meteorology, 29, 596-603.

Tanré, D., Deroo, C., Duhaut, P., Herman, M., Morcrette, J.J., Perbos, J., Deschamps, P.Y., 1990. Description of a computer code to simulate the satellite signal in the solar spectrum: the $5 \mathrm{~S}$ code. International Journal of Remote Sensing, 11, 659-668.

Taylor, V.R., Stowe, L.L., 1984a. Reflectance characteristics of uniform Earth and cloud surfaces derived from Nimbus 7 ERB. Journal of Geophysical Research, 89, 4987-4996.

Taylor, V.R., Stowe, L.L., 1984b. Atlas of reflectance patterns for uniform Earth and cloud surfaces (Nimbus 7 ERB - 61 days), NOAA Technical Report NESDIS 10, July 1984, Washington, DC, USA.

Vermote, E., Tanré, D., Deuzé, J.L., Herman, M., Morcrette, J.J., 1994. Second Simulation of the Satellite Signal in the Solar Spectrum (6S), 6S User Guide, NASA-Goddard Space Flight Center - Code 923, Greenbelt, USA. 
Wald, L., Wald, J.-L., Moussu, G., 1992. A technical note on a low-cost high-quality system for the acquisition and digital processing of images of WEFAX type provided by meteorological geostationary satellites. International Journal of Remote Sensing, 13, 911-916.

Zelenka, A., 2001. Estimating insolation over snow covered mountains with Meteosat VIS-channel: a time series approach. In Proceedings of the Eumetsat Meteorological Satellite Data Users Conference, Eumetsat Publ. EUM P 33, pp, 346-352, Darmstadt, Germany.

Zelenka, A., 2003. Progress in estimating insolation over snow covered mountains with Meteosat VIS-channel: a time series approach. In Proceedings of the $3^{\text {rd }}$ Workshop on Satellites for Solar Energy, March 19-21, 2003. University of Geneva, Switzerland.

Zelenka, A., Czeplak, G., d'Agostino, V., Josefson, W., Maxwell, E., Perez, R., 1992. Techniques for supplementing solar radiation network data, Technical Report, International Energy Agency, \# IEA-SHCP9D-1, Swiss Meteorological Institute, Krahbuhlstrasse, 58, CH-8044 Zurich, Switzerland.

Zelenka, A., Perez, R., Seals, R., Renné D., 1999. Effective accuracy of satellite-derived hourly irradiances. Theoretical and Applied Climatology, 62, 199-207. 